\title{
PENGARUH PERSEPSI KUALITAS, PENGARUH SOSIAL, DAN KEBUTUHAN AKAN KEUNIKAN TERHADAP MINAT PEMBELIAN KONSUMEN LUXURY BRAND PADA GENERASI Y
}

\author{
Dhevina Wangsa Putri dan Louis Utama \\ Program Studi Manajemen Fakultas Ekonomi Universitas Tarumanagara, Jakarta \\ Email: dhevina.115160318@stu.untar.ac.id \\ Email : louisu@fe.untar.ac.id
}

\begin{abstract}
The purpose of this study was to determine 1) whether perceived quality affects the purchase intention of luxury brand consumers in generation $Y$. 2) whether social influence influences affect purchase intention of luxury brand consumers in generation $Y$. 3) whether need of uniqueness affect purchase intention of luxury brand consumers in generation $Y$. The sample used in this study is 40 generation Y consumer respondents who are very aware of the brand. The sampling technique used is non-probability sampling with a purposive sampling method. Overall results of this study are 1) Perceived Quality affects the purchase intention of luxury brand consumers in generation $Y$. 2) Social influence affects purchase intention of luxury brand consumers in generation Y. 3) Need of uniqueness affects purchase intention of luxury brand consumers in generation $Y$.
\end{abstract}

Keywords: Perceived Quality, Social Influence, Need of Uniqueness, Purchase Intention.

Abstrak: Tujuan penelitian ini adalah untuk mengetahui 1) apakah persepsi kualitas berpengaruh terhadap minat pembelian konsumen luxury brand pada generasi Y. 2) apakah pengaruh sosial berpengaruh terhadap minat pembelian konsumen luxury brand pada generasi Y. 3) apakah kebutuhan akan keunikan berpengaruh terhadap minat pembelian konsumen luxury brand pada generasi Y. Sampel yang digunakan pada penelitian ini yaitu 40 responden konsumen generasi $\mathrm{Y}$ yang sangat sadar akan merek. Teknik pengambilan sampel yang digunakan yaitu non-probability sampling dengan metode pengambilan sampel purposive sampling. Secara keseluruhan hasil dari penelitian ini yaitu 1) Persepsi Kualitas berpengaruh terhadap minat pembelian konsumen luxury brand pada generasi Y. 2) Pengaruh Sosial berpengaruh terhadap minat pembelian konsumen luxury brand pada generasi $Y$. 3) Kebutuhan akan Keunikan berpengaruh terhadap minat pembelian konsumen luxury brand pada generasi $\mathrm{Y}$.

Kata kunci: Persepsi Kualitas, Pengaruh Sosial, Kebutuhan akan Keunikan, Minat Pembelian.

\section{LATAR BELAKANG}

Pasar negara berkembang memiliki salah satu permintaan yang tumbuh paling cepat untuk produk merek mewah terdapat di Asia selain di China dan India, adalah Indonesia. Penjualan pasar barang mewah di Indonesia meningkat dengan tinggi sehingga meningkat nya permintaan akan barang-barang mewah, merek fashion dianggap cukup penting memainkan peran dalam mempengaruhi gaya hidup konsumen sekarang ini. Tingginya permintaan akan barang mewah membuat pemilik atau perusahaan merek-merek terkenal tersebut perlu melakukan suatu tindakan yang dapat membuat tingkat nilai minat pembelian 
meningkat. Konsumen generasi Y salah satu konsumen muda yang lahir pada tahun 19771994, mereka sangat sadar akan merek dan bersedia untuk menghabiskan lebih banyak dan berinvestasi dalam produk-produk mewah untuk tingkat kualitas dan rasa yang lebih tinggi. Generasi Y lebih cenderung menggunakan barang branded, karena mereka menganggap hal itu dapat untuk menaikkan harga diri atau prestige dan juga dapat membuat beberapa orang menjadi lebih percaya diri.

Dikarenakan tingginya permintaan akan barang mewah maka pemasar ataupun pemilik merek merek terkenal seperti di atas tersebut harus melakukan suatu kegiatan yang dapat meningkatkan nilai minat pembelian. Untuk mendapatkan minat pembelian yang baik ada beberapa faktor seperti persepsi kualitas yaitu mencerminkan persepsi pelanggan terhadap keseluruhan kualitas atau keunggulan suatu produk atau jasa layanan berkenaan dengan maksud yang diharapkan (Durianto \& Sugiarto, 2004). Selain itu pengaruh sosial juga berpengaruh dalam mempengaruhi minat pembelian. Niat pembelian konsumen untuk barang-barang fashion mewah dipengaruhi secara langsung oleh pengaruh sosial (Algesheimer, Dholakia, \& Herrmann, 2005). Kebutuhan akan keunikan adalah teori yang berputar di sekitar keinginan individu untuk berbeda dari orang lain secara khusus dengan cara di mana individu dianggap memiliki tingkat status sosial yang lebih tinggi (Snyder \& Fromkin, 1977).

\section{KAJIAN TEORI}

Penelitian ini mengacu pada Theory of Planned Behavior (TPB) adalah teori yang menjelaskan perilaku manusia dan terkait dengan keyakinan dan perilaku, yang merupakan perpanjangan dari Theory of Reasoned Action (Fishbein \& Ajzen, 1975). Teori ini dibuat karena adanya keterbatasan yang ada pada model originalnya mengenai perilaku seseorang dalam melakukan sebuah perilaku. Faktor utama dalam Theory of Planned Behavior adalah niat seseorang dalam melakukan sebuah perilaku. Ada berbagai faktor penentu yang mempengaruhi niat dan perilaku konsumen terhadap barang barang fashion mewah di luar dari Theory Planned Behavior seperti teori-teori the perceived quality model, social impact theory, dan theory of uniqueness yang memberikan landasan teoritis dalam penelitian untuk memprediksi perilaku pembelian generasi $\mathrm{Y}$ terhadap niat pembelian barang-barang fashion mewah (Ajzen, 1991).

The Perceived Quality Model adalah salah satu dimensi ekuitas merek dan memiliki dampak yang cukup besar pada citra merek. Kualitas suatu barang yang baik akan menaikan citra merek suatu produk sehingga persepsi konsumen akan produk bagus begitupun sebaliknya, hal ini dapat mempengaruhi minat pembelian konsumen lainnya. Social Impact Theory didefinisikan oleh bagaimana perasaan tanggung jawab konsumen dipengaruhi oleh organisasi besar, status sosial, dan etnis (Danziger, 2007). Media merupakan faktor yang mempengaruhi pembelian dalam luxury product (Nelson \& L.E., 2009). Social Impact Theory sendiri menjelaskan variabel pengaruh sosial. Theory of Uniqueness mendefinisikan kebutuhan konsumen akan keunikan. Teori ini berputar di sekitar keinginan seorang individu untuk berbeda dengan orang lain secara khusus dengan cara di mana individu dianggap memiliki tingkat status sosial yang lebih tinggi (Snyder \& Fromkin, 1977). Theory of Uniqueness mengandung 3 variabel creative choice conformity yang berarti pilihan kreatif yang sesuai dengan pribadi masing-masing konsumen untuk mengembangkan gaya pribadi nya serta inovatif dalam mencoba menampilkan citra diri melalui produk mewah, unpopular choice counter-conformity dimana individu memilih untuk membeli produk yang tidak pasaran, walaupun individu sekalipun memilih pilihan yang tidak popular namun mampu menampilkan keunikan individu dalam jangka panjang dan meningkatkan citra diri konsumen 
bahkan berpotensi membuat individu menonjol dan menjadi pemimpin mode, dan avoidance of similarity yaitu seseorang menghindari kesamaan terhadap orang lain.

\section{Persepsi Kualitas}

Persepsi Kualitas merupakan salah satu asset penting bagi sebuah merek, berikut terdapat beberapa definisi mengenai persepsi kualitas menurut para ahli yaitu persepsi pelanggan terhadap kualitas atau keunggulan suatu produk atau jasa layanan ditinjau dari fungsinya secara relatif dengan produk-produk lain (Pane, 2011). Persepsi kualitas mengacu pada penilaian subyektif konsumen tentang keunggulan suatu merek secara keseluruhan (Amatulli \& Guido, 2011). Masing-masing konsumen memiliki penilaian tersendiri terhadap sebuah produk bermerek yang dinilai dari keunggulan produk tersebut. Konsumen yang memiliki persepsi kualitas baik akan menggunakan barang/jasa dari suatu merek tertentu.

\section{Pengaruh Sosial}

Pengaruh sosial sering kali disebut sebagai faktor lingkungan eksternal yang mempengaruhi seorang individu. Pengaruh sosial mengacu pada bagaimana orang lain memengaruhi keputusan perilaku seseorang, yang berarti bahwa orang lain dapat mempengaruhi perilaku keputusan suatu individu (Wang \& Chou, 2014). Pengaruh sosial dapat didefinisikan sebagai koneksi konsumen individu dengan dunia. Pengaruh sosial menunjukkan persepsi seseorang akan merek dan mempengaruhi keputusan perilaku seseorang dalam menentukan brand. Ketika paparan terhadap dunia meningkat seiring waktu karena globalisasi dan pendidikan asing, konsumen dapat menemukan merek-merek mewah asing yang semakin penting bagi mereka (Mamat \& Noor, 2016).

\section{Kebutuhan akan Keunikan}

Keunikan pada suatu produk dapat mempengaruhi niat beli konsumen, beberapa individu dilaporkan telah membuang barang begitu barang tersebut menjadi barang umum dan sebagainya mencari alternatif yang lebih inovatif dan kurang umum (Bhaduri \& Stanforth, 2016). Yang berarti seorang individu lebih tertarik memiliki barang yang unik dan jarang dimiliki oleh orang lain. Memberikan dukungan bahwa konsumen yang memiliki kebutuhan besar dalam mengekspresikan kepribadian mereka sering membeli pakaian fashion mewah untuk mendapatkan nilai kelangkaan, keunikan dan menghindari kesamaan dengan orang lain dalam hal pakaian (Knight \& Kim, 2007). Hal ini menunjukkan bahwa konsumen yang membeli barang mewah ingin terlihat beda dari individu lain nya serta memiliki keunikan tersendiri.

\section{Minat Pembelian}

Minat pembelian merupakan aspek penting dalam sebuah brand karena menunjukkan minat pembelian, niat pembelian adalah jenis pengambilan keputusan yang mempelajari alasan untuk membeli merek tertentu oleh konsumen (Shah, et al., 2012). Berarti pengambilan keputusan yang dilakukan oleh konsumen terhadap merek tertentu dipengaruhi oleh tingkat nilai pembelian. Selain itu niat pembelian berkaitan dengan empat perilaku konsumen, seperti: rencana yang ragu untuk membeli suatu produk, secara tegas untuk membeli produk, berfikir untuk membeli produk di masa depan dan membeli produk tertentu di masa depan, sehingga bisa saja tidak terburu-buru memutuskan berbelanja dalam jangka waktu yang lama (Tariq \& Iqbal, 2015). Berarti seorang konsumen yang memiliki tingkat minat pembelian yang tinggi maka akan semakin sering untuk membeli produk ketika ke pasar ataupun toko.

Kaitan antara Persepsi Kualitas, Pengaruh Sosial, dan Kebutuhan akan Keunikan. 


\section{a. Kaitan antara persepsi kualitas dan minat pembelian}

Berdasarkan penelitian (Soh, Rezaei, \& Gu, 2017), menjelaskan bahwa konsumen percaya produk mewah memiliki kualitas yang tinggi, tahan lama, dan terkemuka, hal ini menunjukan bahwa persepsi kualitas dapat menaikan perilaku konsumen. Hal ini juga membuat para konsumen untuk membeli barang berdasarkan kualitas barang tersebut. Selain itu berdasarkan penelitian yang dilakukan (Lee, Kim, Pelton, Knight, \& Forney, 2008) yang menunjukan bahwa persepsi kualitas memiliki dampak positif langsung terhadap minat pembelian selain itu juga ditemukan bahwa persepsi kualitas mempengaruhi pilihan pelanggan dan mendorong keputusan pembelian konsumen.

\section{b. Kaitan antara pengaruh sosial dan minat pembelian}

Menurut (Soh, Rezaei, \& Gu, 2017), yang menjelaskan bahwa niat pembelian seseorang dipengaruhi oleh faktor lingkungan dengan kata lain konsumen membeli barang mewah bukan hanya karena selera tetapi juga karena kesesuaian dari masyarakat, dan konsumen sangat mungkin ditekan secara sosial oleh orang-orang yang dekat dengan mereka seperti teman sebaya atau pengaruh media sosial/blogger/selebritas, dengan demikian, ini dapat menghasut mereka untuk memiliki niat untuk membeli barang mewah agar sesuai dengan standar atau harapan masyarakat. Selain itu berdasarkan penelitian (Hung, et al., 2011), menunjukan bahwa pengaruh sosial memiliki dampak positif terhadap minat pembelian, lingkungan sosial juga diyakini dapat mempengaruhi individu karena didorong nya oleh lingkungan eskternal serta pengaruh konsumsi barang mewah.

\section{c. Kaitan antara kebutuhan akan keunikan dan minat pembelian}

Penelitian yang dilakukan oleh (Ahmad \& Ashraf, 2013) menunjukan bahwa kebutuhan akan keunikan memiliki dampak yang kuat terhadap minat pembelian. Penelitian lain yang dilakukan oleh (Aztiani \& Wahab, 2019) pada toko online tas impor anak-anak di Palembang menunjukan bahwa kebutuhan akan keunikan memiliki dampak yang signifikan terhadap minat pembelian, selain itu hasil ini juga menunjukan bahwa semakin tinggi kebutuhan akan keunikan maka semakin tinggi niat pembelian konsumen pada suatu produk.

Berdasarkan pengaruh dari variabel-variabel di atas terhadap minat pembelian konsumen dan penelitian yang relevan sebelumnya maka kerangka konseptual dalam penelitian ini dapat dilihat dalam model penelitian ini : 


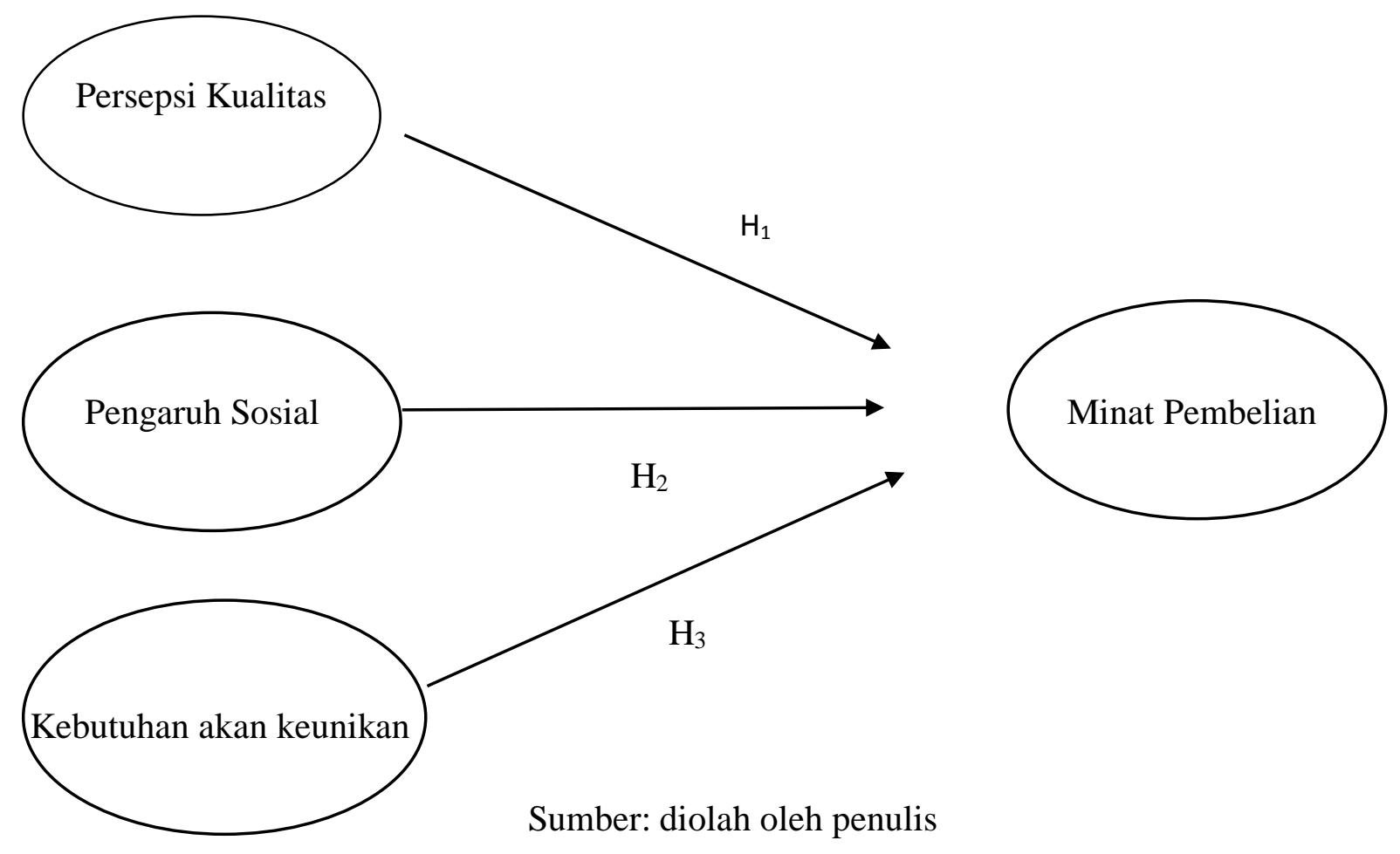

Gambar 1. Model Penelitian

Berdasarkan kerangka pemikiran yang terdapat di atas, maka hipotesis di dalam penelitian ini adalah sebagai berikut :

$\mathrm{H}_{1}$ : Persepsi Kualitas berpengaruh positif terhadap Minat Pembelian konsumen luxury brand.

$\mathrm{H}_{2}$ : Pengaruh Sosial berpengaruh positif terhadap Minat Pembelian konsumen luxury brand.

$\mathrm{H}_{3}$ : Kebutuhan akan keunikan berpengaruh positif terhadap Minat Pembelian konsumen luxury brand.

\section{METODOLOGI}

Penelitian ini merupakan penelitian deskriptif cross sectional. Sampel diambil menggunakan metode nonprobability sampling, tepatnya dengan menggunakan teknik purposive sampling. Hal ini dilakukan pengumpulan data merupakan teknik penentuan sampel penelitian dengan beberapa pertimbangan tertentu yang memiliki tujuan agar data yang diperoleh lebih representatif. Jumlah responden yang diambil oleh peneliti sebanyak 40 responden.

Pengukuran variabel-variabel dalam penelitian ini mengacu pada penelitian sebelumnya antara lain sebagai berikut: 
Tabel 1. Indikator Variabel Penelitian

\begin{tabular}{|c|c|c|}
\hline Variabel & Indikator & Acuan \\
\hline Persepsi Kualitas & 4 item & (Knight \& Kim, 2007) \\
\hline Pengaruh Sosial & 3 item & $\begin{array}{c}\text { (Thomson, Higgins, \& } \\
\text { Howell, 2011) }\end{array}$ \\
\hline Kebutuhan akan Keunikan & 3 item & (Shukla, 2012) \\
\hline Minat Pembelian & 5 item & $\begin{array}{c}\text { (Lee, Kim, Pelton, Knight, \& } \\
\text { Forney, 2008) (Son \& } \\
\text { George, 2013) }\end{array}$ \\
\hline
\end{tabular}

\section{Hasil Uji Statistik}

Hasil Uji validitas dalam penelitian ini dikatakan valid dalam penelitian ini berdasarkan nilai AVE yang diperoleh bernilai lebih besar dari $0,5(>0,5)$ serta nilai loading factor dari setiap indikatornya lebih besar dari $0,7(>0,7)$. Hasil uji reliabilitas dalam penelitian ini dikatakan reliabel berdasarkan hasil analisis dengan menggunakan pendekatan Cronbach's Alpha maupun Composite Reliability pada item untuk setiap variabel yang lebih dari 0,6. Sedangkan, discriminant validity terdiri dari analisis fornell-larcker dan cross loading.

Hasil yang diperoleh dalam penelitian ini menunjukkan bahwa nilai yang diperoleh telah memenuhi syarat cross-loadings dan fornell-larcker. Koefisien determinasi $\left(\mathrm{R}^{2}\right)$ digunakan untuk mengukur seberapa besar variabel persepsi kualitas, pengaruh sosial, dan kebutuhan akan keunikan dapat menjelaskan variabel minat pembelian nilai $\left(R^{2}\right)$ sebesar 0,953 menjelaskan bahwa sebesar 95,3\% dapat dijelaskan oleh variabel-variabel yang terdapat pada penelitian ini, dan sisanya sebesar 4,7\% dapat dijelaskan oleh variabel-variabel lain yang tidak diteliti dalam penelitian ini. Selanjutnya, hasil pengujian Q-Square menunjukan nilai sebesar 0,738 untuk minat pembelian yang artinya nilai predictive relevance $\left(\mathrm{Q}^{2}\right)$ dalam penelitian ini lebih besar dari 0 (nol).

Hasil analisis data secara singkat dapat dilihat pada Tabel 2.

Tabel 2. Hasil Pengujian Hipotesis

\section{Variabel}

Persepsi Kualitas => Minat Pembelian

Pengaruh Sosial $=>$ Minat Pembelian

Kebutuhan akan Keunikan => Minat Pembelian

\section{Path Coefficient}

$$
0,425
$$

0,300 t-statistics

2,097 p-values

0,000

0,014

0,037

Berdasarkan pada hasil dari pengujian bootstrapping yang ditampilkan pada Tabel 1 di atas, maka terdapat persamaan untuk variabel minat pembelian yang dapat dijelaskan sebagai berikut : Minat Pembelian $=0,425$ Persepsi Kualitas + 0,270 Pengaruh Sosial + 0,300 Kebutuhan akan Keunikan. Berdasarkan persamaan tersebut dapat dikatakan bahwa variabel independen $(\mathrm{X})$ yaitu persepsi kualitas memiliki hubungan yang positif terhadap variabel dependen $(\mathrm{Y})$ yaitu minat pembelian, variabel independen $(\mathrm{X})$ yaitu pengaruh sosial juga memiliki hubungan yang positif terhadap variabel dependen (Y) yaitu minat pembelian, dan 
variabel independen (X) kebutuhan akan keunikan juga memiliki hubungan yang positif terhadap variabel dependen (Y) yaitu minat pembelian. Selain itu, dilakukan pula pengujian goodness of fit (GoF). Hasil perhitungan menunjukan hasil yang menyatakan model yang digunakan dalam penelitian ini memiliki nilai GoF sebesar 0,911. Maka dapat dikatakan model yang digunakan di dalam penelitian ini merupakan kecocokan model penelitian yang tergolong besar. Sesuai dengan (Akter \& Ray, 2010) yang menyatakan bahwa nilai GoF kecil sebesar 0,1, nilai GoF sedang 0,25 dan nilai GoF besar 0,36.

\section{DISKUSI}

Pada bagian ini akan dilakukan pembahasan dan penjelasan mengenai hasil dari penelitian yang telah dilakukan oleh peneliti. Penelitian yang dilakukan ini menggunakan 40 responden yang dimana konsumen luxury brand yang sadar akan merek dan pernah membeli salah satu produk luxury brand tas (Louis Vuitton, Gucci, Channel, dan Hermes) pada generasi Y dimana kelahiran pada tahun 1977-1994. Jumlah responden dalam penelitian ini sesuai dengan pendapat dari Malhotra (2004) yang mengatakan apabila dalam sebuah penelitian dilakukan analisis multivariate (korelasi atau regresi ganda), maka dari itu jumlah sampel minimal 10 kali dari jumlah variabel yang akan diteliti. Penelitian yang dilakukan ini memiliki responden dengan karakteristik jenis kelamin perempuan sebanyak 26 orang responden $(65 \%)$ dan berjenis kelamin laki-laki sebanyak 14 orang responden $(35 \%)$.

Sebagian besar dari responden kuisioner ini berusia 32 sampai 37 tahun sebanyak 22 responden dengan presentase sebesar 55\%. Selain itu usia 26 sampai 31 tahun sebanyak 14 responden dengan presentase sebesar 35\% dan usia 38 sampai 43 tahun mempunyai 4 responden yang paling sedikit dengan presentase sebesar $10 \%$. Dalam penelitian ini juga 40 responden pernah membeli luxury brand tas.

Pengujian validitas dan reliabilitas data dalam penelitian ini menggunakan hasil dari pengujian outer model yang sudah dilakukan dimana nilai outer loading yang didapat pada setiap indikator memiliki nilai lebih besar dari 0,5 dan nilai AVE (Average Variance Extracted) diatas 0,5 sehingga nilai discriminant validity dapat memenuhi kriteria. Maka dari itu dapat disimpulkan bahwa data pada penelitian ini valid. Berikutnya hasil uji reliabilitas pada penelitian ini menggunakan cronbach's alpha dan composite reliability. Hasil uji cronbach's alpha pada setiap variabel memiliki nilai diatas 0,6 dan hasil composite reliability pada setiap variabel memiliki nilai diatas 0,7 . Sehingga data pada penelitian ini dikatakan reliabel karena sudah memenuhi kedua kriteria tersebut. Data yang sudah valid dan reliabel ini kemudia diolah dengan menggunakan analisis koefisien determinasi $\left(\mathrm{R}^{2}\right)$. Koefisien determinasi $\left(\mathrm{R}^{2}\right)$ digunakan untuk mengetahui seberapa besar kontribusi variabel persepsi kualitas, pengaruh sosial, dan kebutuhan akan keunikan terhadap minat pembelian. Hasil pengujian analisis koefisien determinasi $\left(\mathrm{R}^{2}\right)$ pada penelitian ini adalah sebesar 0,953 atau 95,3\%. Berdasarkan hasil dari koefisien determinasi $\left(\mathrm{R}^{2}\right)$ maka dapat diketahui bahwa persepsi kualitas, pengaruh sosial, kebutuhan akan keunikan memiliki kontirbusi yang kuat terhadap minat pembelian sebesar $95,3 \%$ dan dapat dikatakan koefisien determinasi $\left(\mathrm{R}^{2}\right)$ dalam penelitian ini memiliki kontribusi yang kuat sedangkan $4,7 \%$ kontribusi terhadap minat pembelian ditentukan oleh variabel lain yang tidak terdapat dalam penelitian ini. Setelah melewati analisis koefisien determinasi $\left(\mathrm{R}^{2}\right)$ maka dilakukan uji $Q$-Square dengan metode blindfolding memiliki nilai 0,738 menunjukan bahwa variabel persepsi kualitas, pengaruh sosial, dan kebutuhan akan keunikan memiliki pengaruh yang kuat terhadap minat pembelian.

Setelah itu pengujian hasil dari path coefficients dalam penelitian ini dengan Minat Pembelian $=0,425$ Persepsi Kualitas $+0,270$ Pengaruh Sosial $+0,300$ Kebutuhan akan Keunikan, dan mendapatkan hasil sebesar 0,911 yang menunjukkan bahwa kecocokan dan tingkat kelayakan model penelitian ini tergolong tinggi. Berdasarkan persamaan tersebut 
dapat menunjukkan bahwa hubungan variabel persepsi kualitas, pengaruh sosial, dan kebutuhan akan keunikan terhadap minat pembelian berpengaruh secara signifikan. Selanjutnya pengujian Goodness of Fit $(\mathrm{GoF})$, pengujian ini dilakukan untuk mengetahui kecocokan model yang terdapat dalam penelitian ini. Hasil perhitungan dari penelitian ini Goodness of Fit sebesar 0,911 maka dapat dikatakan bahwa model yang digunakan dalam penelitian ini merupakan kecocokan model penelitian yang tergolong besar.

Pembahasan uji hipotesis (path coefficient) dimana pada penelitian ini menggunakan metode bootstrapping. Berikut merupakan hipotesis yang telah dibuat oleh penulis : (H1o) : Tidak terdapat pengaruh persepsi kualitas terhadap minat pembelian konsumen luxury brand pada Generasi Y. (H1a) : Terdapat pengaruh persepsi kualitas terhadap minat pembelian konsumen luxury brand pada Generasi Y. Berdasarkan hasil dari penelitian ini dapat diketahui bahwa H1o ditolak. Hasil pengujian hipotesis ini sesuai dengan penelitian yang dilakukan oleh (Lee, Kim, Pelton, Knight, \& Forney, 2008) yang menunjukkan bahwa persepsi kualitas memiliki dampak langsung terhadap minat pembelian selain itu, persespi kualitas juga mempengaruhi pilihan pelanggan dan mendorong keputusan pembelian konsumen, sebagian konsumen dapat merasakan kualitas produk dan meningkatkan niat beli mereka.

Selanjutnya, dari hasil pengujian hipotesis kedua (H2o) : Tidak terdapat pengaruh dari pengaruh sosial terhadap minat pembelian konsumen luxury brand pada Generasi Y. (H2a) : Terdapat pengaruh dari pengaruh sosial terhadap minat pembelian konsumen luxury brand pada Generasi Y. Berdasarkan hasil penelitian ini dapat diketahui bahwa H2o ditolak. Hasil pengujian hipotesis ini sesuai dan diperkuat dengan penelitian yang dilakukan oleh (Mamat \& Noor, 2016), yang menyatakan bahwa pengaruh sosial sebagai koneksi konsumen dengan dunia. Ketika paparan terhadap dunia meningkat seiring berjalannya waktu karena globalisasi dan pendidikan asing, konsumen dapat menemukan merek merek mewah asing yang penting bagi mereka. Hal ini merupakan sangat penting bagi merek-merek mewah yang dikenal secara internasional. Niat pembelian konsumen khusus nya pada generasi Y sebagian dibentuk oleh pengaruh lingkungan (Cheah \& Shimul, 2015) mereka cenderung memperhatikan lingkungan sekitar untuk memutuskan membeli suatu barang.

Selanjutnya, dari hasil pengujian hipotesis ketiga (H3o) : Tidak terdapat pengaruh kebutuhan akan keunikan terhadap minat pembelian konsumen luxury brand pada Generasi $\mathrm{Y}$ (H3a) : Terdapat pengaruh kebutuhan akan keunikan terhadap minat pembelian konsumen luxury brand pada Generasi Y. Berdasarkan dari hasil penelitian ini dapat diketahui bahwa H3o ditolak. Hasil dari pengujian hipotesis tersebut sesuai dengan penelitian (Bhaduri \& Stanforth, 2016), yang menyatakan bahwa konsumen yang memiliki kebutuhan tinggi dalam mengekspresikan kepribadian mereka sering memiliki niat untuk membeli barang-barang fashion mewah untuk mendapatkan nilai kelangkaan, keunikan, menghindari kesamaan dan bahkan berpotensi menjadikan individu sebagai pemimpin mode. Selain itu hipotesis ni juga relevan dengan penelitian yang dilakukan oleh (Tariq \& Iqbal, 2015) yang menyimpulkan bahwa semakin tinggi tingkat kebutuhan akan keunikan akan menimbulkan juga naiknya minat pembelian konsumen.

\section{PENUTUP}

Dari hasil uraian dan analisis yang telah dilakukan, dapat diketahui bahwa persepsi kualitas, pengaruh sosial, dan kebutuhan akan keunikan dapat mempengaruhi secara positif dan signifikan terhadap minat pembelian. Peneliti menyarankan perusahaan luxury brand juga perlu meningkatkan persepsi kualitas pada konsumen, karena hal tersebut merupakan penilaian umum yang subjektif dari pihak konsumen terhadap suatu produk. Selain itu peneliti menyarankan perusahaan luxury brand untuk terus mengembangkan dan 
meningkatkan kualitas produk karena dilihat dari nilai rata-rata terendah terdapat pada indikator ke tiga dari persepsi kualitas yaitu pernyataan, saya berpikir bahwa barang fashion mewah tahan lama. Sehingga peneliti menyarankan untuk perusahaan luxury brand selalu menjaga kualitas produk tersebut agar konsumen akan tetap memilih produk dan membeli nya. Selain itu, perusahaan perlu meningkatkan nilai keunikan dari setiap produk karena terbukti bahwa konsumen mempunyai nilai keunikan masing-masing yang ingin membedakan dirinya dengan orang lain tinggi.

Selain itu juga peneliti menyarankan untuk perusahaan luxury brand akan mempromosikan produk-produknya dengan cara melalui influencer yang terkenal dikalangan masyarakat karena terbukti dalam penelitian ini konsumen menggunakan produk produk luxury brand karena juga terpengaruh oleh lingkungan sosial mereka. Baiknya perusahaan untuk meningkatkan dan terus mempromosikan melalui media social seperti dengan cara menggunakan endorsement dari selebritas untuk melakukan promosi ataupun influencer dan juga brand ambassador karena pengaruh sosial semakin memiliki pengaruh yang kuat pada minat pembelian konsumen.

\section{DAFTAR PUSTAKA}

Algesheimer, R., Dholakia, U.M. and Herrmann, A. (2006), "The social influence of brand community: evidence from European car clubs", Journal of Marketing, 69(3), 19-34.

Amatulli, C. and Guido, G. (2011), "Determinants of purchasing intention for fashion luxury goods in the Italian market: a laddering approach", Journal of Fashion Marketing and Management: An International Journal, 15(1), 123-136.

Armstrong, G. danand Kotler, P. (2003), Marketing: An Introduction, 6th ed., Pearson Prentice Hall, New Jersey.

Aztiani, D., Wahab, Z., \& Andriana, I. (2019). The effect of perceived quality, perceived price and need for uniqueness on consumer's purchase intention through online store of children import bag in palembang, Indonesia. International Journal of Scientific and Research Publications (IJSRP), 9(8).

Cheah, I., Phau, I., Chong, C., \& Shimul, A. S. (2015). Antecedents and outcomes of brand prominence on willingness to buy luxury brands. Journal of Fashion Marketing and Management: An International Journal, 19(4), 402-415.

Danziger, P. (2007), Let Them Eat Cake: Marketing Luxury to the Masses-as well as the Classes, Dearborn Trade Publishing, Chicago.

Fishbein, M. and Ajzen, I. (1975), Belief, Attitude, Intention and Behaviour: An Introduction to Theory and Research, Addison-Wesley, Reading, MA.

Hung, K. P., Chen, A. H., Peng, N., Hackley, C., Tiwsakul, R. A., \& Chou, C. L. (2011). Antecedents of luxury brand purchase intention. Journal of Product \& Brand Management, 20(6), 457-467.

Garson, G. D. (2016). Partial least squares: Regression and structural equation models. Asheboro, NC: Statistical Associates Publishers.

Garson, G. D. (2016). PARTIAL LEAST SQUARES (PLS-SEM): Regression and Structural Equation Models. North Carolina: Statistical Publishing Associates.

Hung, K., Chen, A. H., Peng, N., Hackley, C., Tiwsakul, R. A., \&amp; Chou, C. (2011). Antecedents of luxury brand purchase intention. Journal of Product \&amp; Brand Management, 20(6), 457-467.

Hussein, A. S. (2015). Penelitian bisnis dan manajemen menggunakan partial least squares (pls) dengan smartPLS 3.0. Universitas Brawijaya.

Lee, J. E., Goh, M. L., \& Noor, M. N. B. M. (2019). Understanding purchase intention of university students towards skin care products. PSU Research Review, 3(3), 161-178. 
Lee, M. Y., Kim, Y. K., Pelton, L., Knight, D., \& Forney, J. (2008). Factors affecting Mexican college students purchase intention toward a US apparel brand. Journal of Fashion Marketing and Management: An International Journal, 12(3), 294-307.

Liao, J. dan Wang, L. (2009), "Face as a mediator of the relationship between material value and brand consciousness", Psychology and Marketing, Vol. 26 No. 11, pp. 987-1991.

Malhotra, N. K. (2015). Essentials of marketing research: A hands-on orientation. Essex: Pearson

Mamat, M. N., Noor, N. M., \& Noor, N. M. (2016). Purchase intentions of foreign luxury brand handbags among consumers in Kuala Lumpur, Malaysia. Procedia Economics and Finance, 35, 206-215.

Park, H. J., Rabolt, N. J., \& Jeon, K. S. (2008). Purchasing global luxury brands among young Korean consumers. Journal of Fashion Marketing and Management: An International Journal, 12(2), 244-259.

Soh, C. Q., Rezaei, S., \&amp; Gu, M. (2017). A structural model of the antecedents and consequences of Generation Y luxury fashion goods purchase decisions. Young Consumers, 18(2), 180-204.

Snyder, C.R. dan Fromkin, H.L. (1977), "Abnormality as a positive characteristic: the development and validation of a scale measuring need for uniqueness", Journal of Abnormal Psychology, 86(5), 518-527.

Tian, K.T. and McKenzie, K. (2001), “The long-term predictive validity of the consumers' need for uniqueness scale", Journal of Consumer Psychology, 10 (3), 171-93.

Tian, K.T., Bearden, W. and Hunter, G. (2001), "Consumers' need for uniqueness: scale development and validation", Journal of Consumer Research, 28(1), 50-66.

Wang, P.Z. and Waller, D.S. (2008), "Measuring consumer vanity: a cross-cultural validation", Psychology \& Marketing, 23(8), 665-687.

Wang, E. S.-T., \& Chou, N. P.-Y. (2014). Consumer characteristics, social influence, and system factors on online group-buying repurchasing intention. Journal of Electronic Commerce Research, 15(2), 119-132.

White, S. (2019, November 28). Hong Kong loses luster for luxury brands as mainland China shines: Bain. Retrieved June 01, 2020, from https://www.reuters.com/article/us-luxurybain/hong-kong-loses-luster-for-luxury-brands-as-mainland-china-shines-bainidUSKBN1Y21JI.

Workman, J.E. and Lee, S.H. (2013), "Vanity and public self-consciousness: a comparison of fashion consumer groups and gender", International Journal of Consumer Studies, 35(3), 307-315.

Yan, L., Xiaojun, F., Li, J., \& Dong, X. (2019). Extrinsic cues, perceived quality, and purchase intention for private labels. Asia Pacific Journal of Marketing and Logistics, 31(3), 714-727.

Zeithaml, V.A. (1988), "Consumer perceptions of price, quality, and value: a means-end model and synthesis of evidence", Journal of Marketing, 52(3), 2-22. 